\title{
SMARCB1 wt Allele
}

National Cancer Institute

\section{Source}

National Cancer Institute. SMARCB1 wt Allele. NCI Thesaurus. Code C52113.

Human SMARCB1 wild-type allele is located in the vicinity of 22q11.2 and is approximately $48 \mathrm{~kb}$ in length. This allele, which encodes SWI/SNF related, matrix associated, actin dependent regulator of chromatin, subfamily $B$, member 1 protein, plays a role in both the promotion of transcriptional activity and the modification of chromatin structure. The gene is mutated in malignant rhabdoid tumors and many epithelioid sarcomas. 